\title{
Assessment of the Properties of Rubberized Bama Gravel Concrete using Destructive Method
}

\author{
A. T. Gubio' ${ }^{1}$, L. O. Onundi2, Y. G. Balami ${ }^{1}$
}

${ }^{1}$ Civil Engineering Department, Ramat Polytechnic, Maiduguri, Borno State

${ }^{2}$ Civil Engineering Department, University of Maiduguri, Borno State

\begin{abstract}
From the twentieth first century to date, the world has seen a rapid production of non-biodegradable materials like rubber with some having less than a decade expiry date such as vehicle tyres. This has generated enormous amount of solid waste which can be best managed by recycling methods; recycling in concrete is one possible means of achieving this goal since it's the single most widely used material in the world. Although concrete compressive strength is reduced by addition of rubber depending on the percentage of rubber added and the average size of rubber used as aggregate. This study investigates Rubberized Bama Gravel concrete (RBGC) when three varied contents of rubber $(10 \%, 20 \%$ and $30 \%$ by mass) were used to replace the mineral aggregate for both fine and coarse rubber aggregates respectively as compared to the controlled mix. A mix ratio of 1:11/2:3 and 1:2:4, and water cement ratio of 0.5 and 0.6 were respectively used during the investigation. Tests carried out on Bama aggregate were specific gravity, aggregate impact and aggregate crushing; and on concrete are workability, density and destructive compressive strength. The study has shown that rubberized concrete is weak in compressive strength. But they have good water resistance with low absorption, low shrinkage and high impact resistance. The reduction in compressive strength of $10 \%$ fine rubber aggregate is about $10 \%$ which could be used as a structural member, while others $(20 \%, 30 \%$ fine rubber aggregate and 10\%, 20\%, 30\% chipped rubber aggregate) cannot be used as structural members as there is a significant decrease in compressive strength of concrete but rather as floors, kerbs, blocks and other non-structural.
\end{abstract}

Keywords: Rubberized Concrete, Bama Gravel, Structural Member

\subsection{Introduction}

Over the last two centuries, the world has seen rapid production of rubber especially vehicle tyres, which constitute a major part of solid waste. About 1.5 billion new tyres are produced yearly in this industry (Almaleeh, Shitote, \& Nyomboi, 2017) of which some are recycled. Rubberized concrete is an alternate source for recycling this waste as they change the properties of the concrete.

(Almaleeh et al., 2017) carried out use of waste rubber tyres as aggregate for possible application in the construction industry. In the first phase, fine rubber tyres aggregates were used to replace $50 \%$ of the normal sand. Secondly, coarse rubber aggregates tyres were used in the replacement of $50 \%$ of the normal gravel. Finally, both fine and coarse rubber tyres aggregates were used to replace the sand and gravel by $25,50,75$ and $100 \%$. It concludes that rubberized concrete could be used as foot paths, sports field such as tennis, volley ball, basket ball as the compressive strength of concrete is reduced with increase in rubber.
(Mavoulidou \& Figueiredo, 2010) carried out a research aimed at performing a set of consistent tests for a wide range of physical and mechanical properties and behaviour of concrete containing rubber aggregate. In the first set of mixes, the coarse rubber aggregate (CRA) replaced part of the coarse mineral aggregate (CMA) of the control mix. In the second, fine rubber aggregate (FRA) replaced partly fine mineral (stone) aggregate (FMA) of the control mix. Four different contents of rubber aggregate (by mass) were used to replace the mineral aggregate $(10 \%, 20 \%, 30 \%$ and $40 \%$ respectively). It concludes that despite the observed lower values of the mechanical properties of concrete there is a potential large market for concrete products in which inclusion of rubber aggregate would be feasible. These can also include non primary structural applications of medium to low strength requirements, benefiting from other features of this type of concrete. Even if rubber tyre aggregate was used at relatively low percentages in concrete, the amount of waste tyre rubber could be greatly reduced due to the very large market for concrete products worldwide.

This article is published under the terms of the Creative Commons Attribution License 4.0 Author(s) retain the copyright of this article. Publication rights with Alkhaer Publications.

Published at: http://www.ijsciences.com/pub/issue/2018-04/

DOI: 10.18483/ijSci.1624; Online ISSN: 2305-3925; Print ISSN: 2410-4477 
Therefore the use of discarded tyre rubber aggregates in concrete shows promise for developing an additional route for used tyres.

This paper explores used rubber tyres grinded into fine and chipped forms to partially replace fine and coarse mineral aggregate respectively in concrete. It investigates its application in the construction industry in the production of non structural members such as kerbs, blocks, sports field ground.

\subsection{EXPERIMENTAL DESIGN \\ 2.1 Materials}

The materials that were used to develop the concrete mixtures in this study are cement, fine aggregate (sand), coarse aggregate (Bama gravel), water, chipped and crumb tyre rubber in Figure 3 (Kamil, Kaloush, George, B., \& P.E., 2005; Onundi, Izam, \& Umar, 1999). The cement that was used for the research work is Ordinary Portland Cement (Ashaka Cement) Product Registration Number NI5996: 2003-4. NIS 444:2003-CEM II/A-L 32.5R. Alau River sand was used as fine aggregate, and natural river gravel locally called Bama gravel was used as coarse aggregate (Onundi et al., 1999) both located at Alau and Bama Local Government Area in Borno State of Nigeria with geographical coordinates of $11^{0}$ 31 '6" North and $13^{\circ} 41$ ' 21 " East. Used rubber tyres were cut manually and classified into two; chipped and fine rubber. Chipped rubber aggregates were used to replace the coarse mineral aggregate while fine rubber aggregates were used to replace the fine mineral aggregate. For both the rubber and mineral aggregates, particle sizes passing through a $2.36 \mathrm{~mm}$ B.S. sieve were adopted as fine aggregate while those retained by the $5 \mathrm{~mm}$ B.S. sieve were adopted as coarse aggregate. Potable water obtained from the Civil Engineering Laboratory, Ramat Polytechnic, Maiduguri, Borno State was used for the work according to BS $3148,1986$.

\subsection{Test Methods}

The following testes were carried out on the aggregate:

i.Sieve Analysis was carried out according to BS 410-1, 2: 2000 river mineral and rubber fine and coarse aggregates.

ii.Specific Gravity was carried out according to BS 882: 1992 on river mineral fine and coarse aggregate.

iii.Aggregate Impact Test was carried out according to BS 812-112: 1990 on Bama river mineral gravel.

iv.Aggregate Crushing Test was carried out according to BS 812-110 1990 on Bama river mineral gravel.

The following testes were carried out on the aggregate

i.Slump test was carried out according to BS EN 12350-2: 2000 on fresh concrete.
ii.Destructive compressive test was conducted according to BS EN 12390-1:2009 on hardened concrete.

\subsection{TEST PROGRAM}

The study involved partial replacement of rubber tyre aggregate particles with mineral aggregate in the production of concrete. Initially normal concrete of control mix of $1: 1 \frac{1}{2}: 3$ and $1: 2: 4$ mix ratios, using 0.5 and 0.6 water-cement ratio were produced. This is to create a reference to check the reduction in density and loss in strength concrete. Furthermore rubberized concrete with partial replacement of fine mineral aggregate with fine rubber aggregate at $10 \%, 20 \%$, and $30 \%$ was carried out, and then coarse mineral aggregate was also replaced with chipped mineral aggregate at $10 \%, 20 \%$, and $30 \%$ in Figure 4 . The three phase's proportions were as illustrated in Table 2 . This is to know the rate of reduction in strength with increase in percentage rubber. Specific gravity test, aggregate impact and crushing tests were conducted on the aggregate, while slump test in Figure 5, density test and compressive strength test were conducted on the concrete. Cubes of $150 \mathrm{~mm} \times 150 \mathrm{~mm} \times 150 \mathrm{~mm}$ were tested after curing for 7 and 28 days respectively.

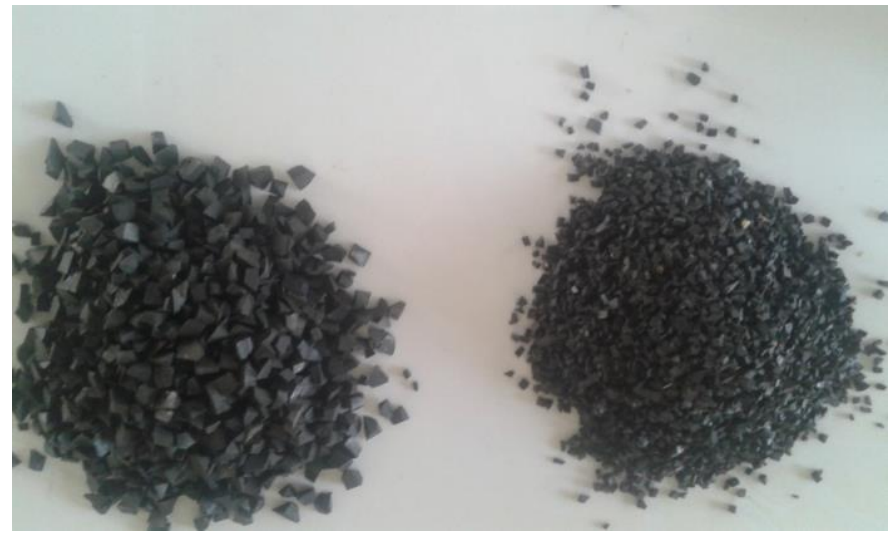

Figure 1: Chipped and Fine rubber aggregate.

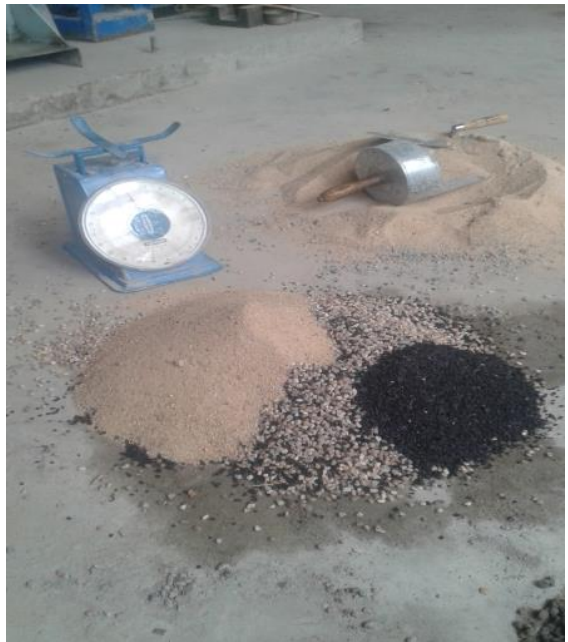

Figure 2: Measured Sample of aggregate 


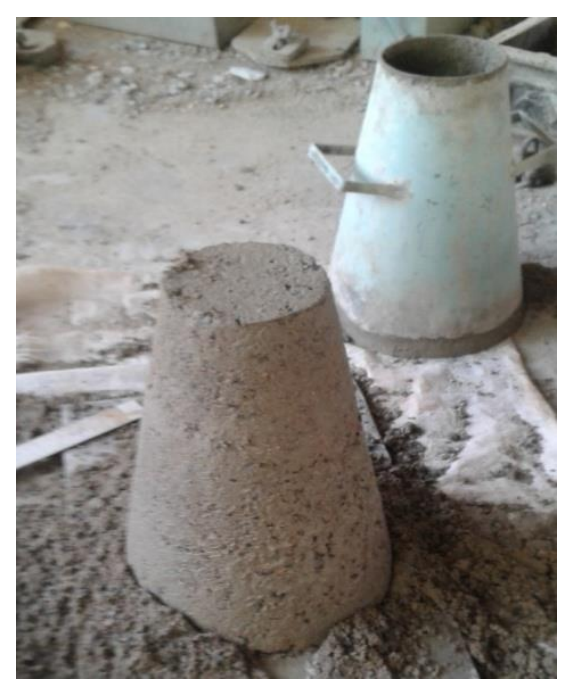

Plate No. 3: Slump test

Table 1: Tests of the normal aggregate

\begin{tabular}{lcc} 
Type of Test & Fine aggregate & Coarse aggregate \\
\hline Specific gravity & 2.61 & 2.61 \\
A.I.V. $(\%)$ & - & 16 \\
A.C.V. $(\%)$ & - & 33 \\
\hline
\end{tabular}

Table 2: Proportion of Concrete Mix Design

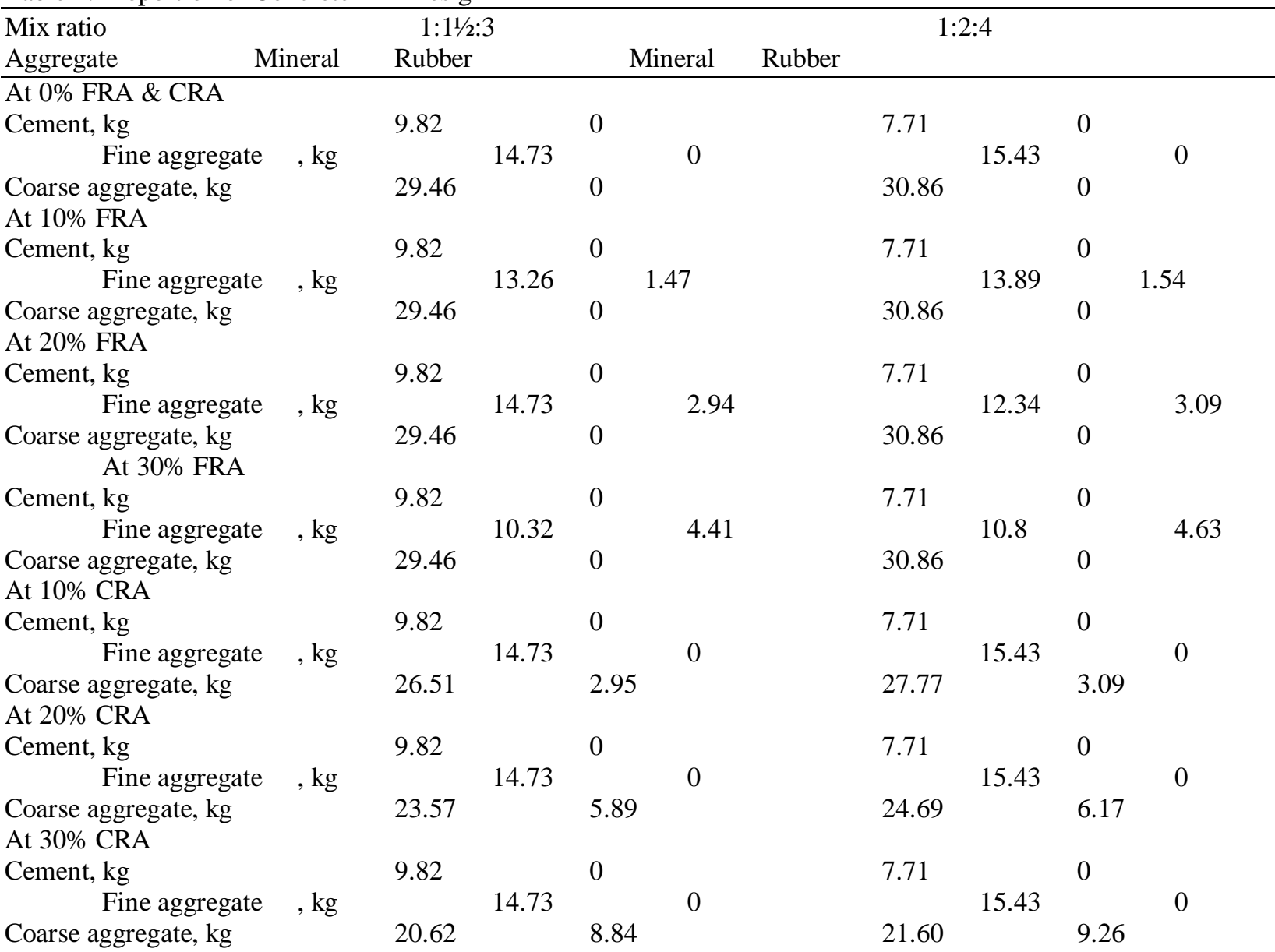




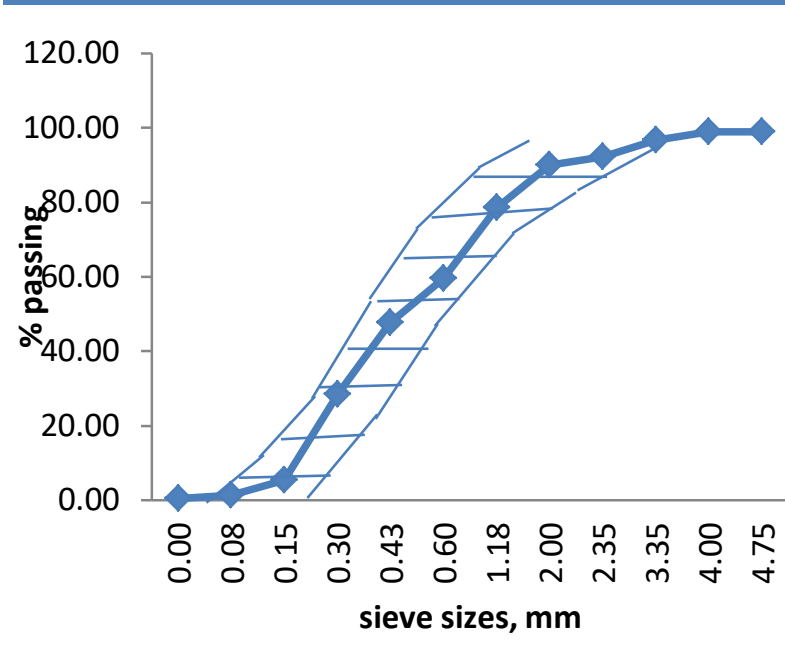

Figure 3: Sieve analysis for Alau River Sand.

\subsection{Experimental Results and Discussion 3.1 Results}

The slump for rubberized concrete as compared to control mix ranges from $7 \mathrm{~mm}$ to $14 \mathrm{~mm}$ at control mix, $8 \mathrm{~mm}$ to $25 \mathrm{~mm}$ with fine rubber aggregate and $9 \mathrm{~mm}$ to $189 \mathrm{~mm}$ with chipped rubber aggregate. This indicated that change in slump was insignificant in all cases except at $30 \%$ chipped rubber which shows a collapse slump from $150 \mathrm{~mm}$ to $189 \mathrm{~mm}$. this is illustrated in Figures (5, 6, 7 and 8).

From Figures (9 to 12), it can be seen that there is a constant decrease in density with increase in rubber aggregate percentage from $10 \%$ to $30 \%$ i.e. from an average of $2400 \mathrm{~kg} / \mathrm{m}^{3}$ at control mix, $2300 \mathrm{~kg} / \mathrm{m}^{3}$ at $10 \%, 2200 \mathrm{~kg} / \mathrm{m}^{3}$ at $20 \%$ and $2100 \mathrm{~kg} / \mathrm{m}^{3}$ at $30 \%$ rubber aggregate. This shows a decrease of about $5 \%$ in density of rubberized concrete at each increase in percentage rubber from the control.

Finally, there was a significant decrease in compressive strength of rubberized concrete as compared to control mix depending on the percentage of rubber increased and the type of rubber used (i.e. fine or chipped) is shown in Figures 13, 14, 15 and 16.

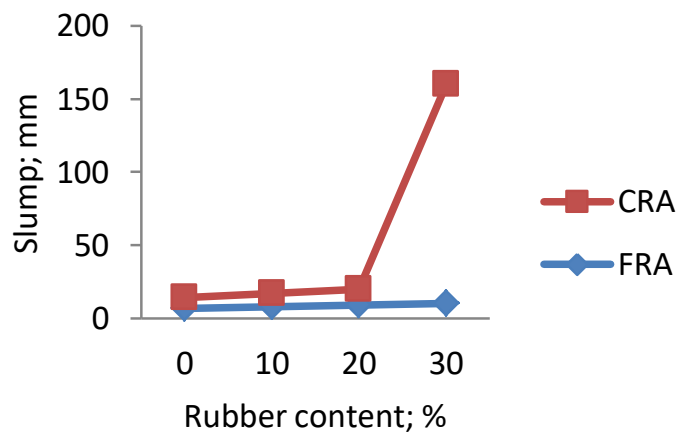

Figure 5: Workability of $1: 1 \frac{1 / 2: 3}{2}$ at w/c of 0.5

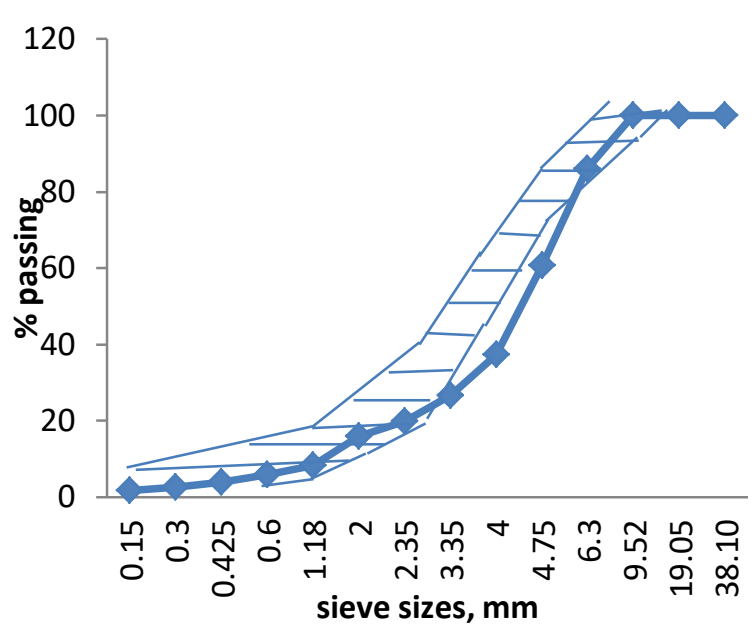

Figure 4: Sieve analysis for Bama Gravel

For fine rubber, at $1: 1 \frac{1 / 2: 3}{2}$ and $0.5 \& 0.6 \mathrm{w} / \mathrm{c}$ ratio, the average values for control is $25 \mathrm{~N} / \mathrm{mm}^{2}$ and rubberized concrete are $20 \mathrm{~N} / \mathrm{mm}^{2}, 13 \mathrm{~N} / \mathrm{mm}^{2}$ and 7 $\mathrm{N} / \mathrm{mm}^{2}$ while for $1: 2: 4$ is $20 \mathrm{~N} / \mathrm{mm}^{2}$ and rubberized concrete are $20 \mathrm{~N} / \mathrm{mm}^{2}, 13 \mathrm{~N} / \mathrm{mm}^{2}$ and $7 \mathrm{~N} / \mathrm{mm}^{2}$ for $10 \%, 20 \%$ and $30 \%$ respectively at 28 days.

For chipped rubber, at $1: 1 \frac{1}{2}: 3$ and $0.5 \& 0.6 \mathrm{w} / \mathrm{c}$ ratio, the average values for control is $25 \mathrm{~N} / \mathrm{mm}^{2}$ and rubberized concrete are $11 \mathrm{~N} / \mathrm{mm}^{2}, 6 \mathrm{~N} / \mathrm{mm}^{2}$ and 3 $\mathrm{N} / \mathrm{mm}^{2}$, while for $1: 2: 4$ is $20 \mathrm{~N} / \mathrm{mm}^{2}$ and rubberized concrete are $10 \mathrm{~N} / \mathrm{mm}^{2}, 5 \mathrm{~N} / \mathrm{mm}^{2}$ and $2 \mathrm{~N} / \mathrm{mm}^{2}$ for $10 \%, 20 \%$ and $30 \%$ respectively at 28 days.

Analytically, the drop in compressive strength amounts to $72 \%$ and $88 \%$ when fine and chipped rubber aggregate are added to the concrete.

During the process of crushing of cubes, unlike the normal concrete the rubberized concrete does not scatter when the cubes are crushed. Instead, they maintain their shapes. This is due to the elastic nature of the cubes as a result of inclusion of rubber which makes it to be elastic and ductile.

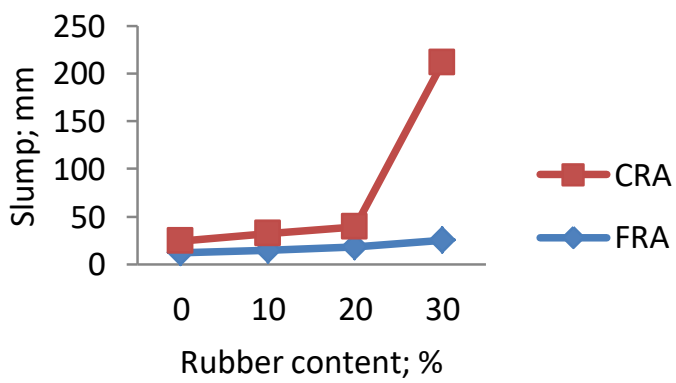

Figure 6: Workability of $1: 1 \frac{1 / 2: 3}{\text { at w/c of } 0.6}$ 


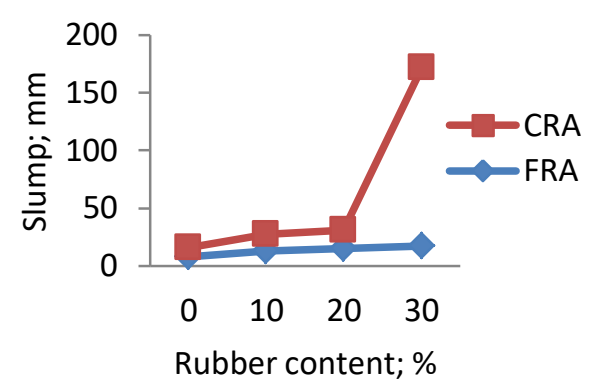

Figure 7: Workability of 1:2:4 at w/c of 0.5

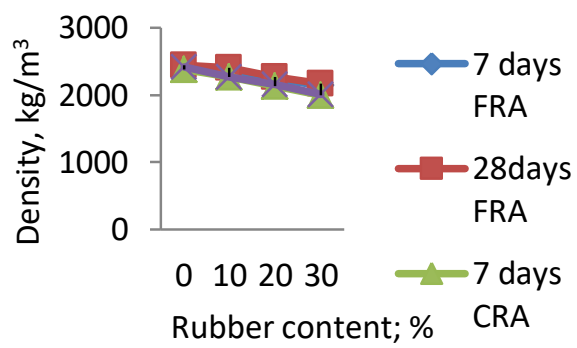

Figure 9: Densities of Mix Proportion 1:11/2:3 at w/c of 0.5 of 0.6

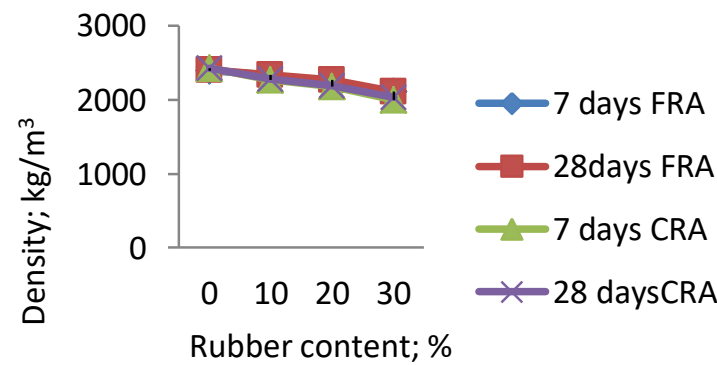

Figure 11: Densities of Mix Proportion 1:2:4 at w/c of 0.5. of 0.6

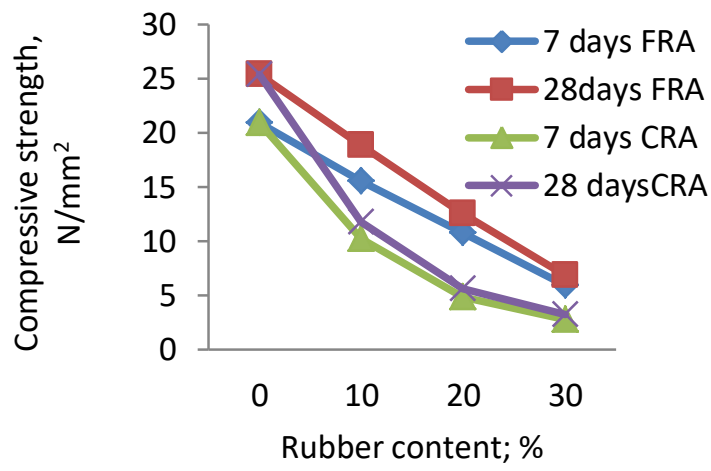

Figure 13: Compressive Strength Tests of 1:11/2:3 of 0.5 Figure 14: Compressive Strength Tests of 1:11/2:3 of 0.6

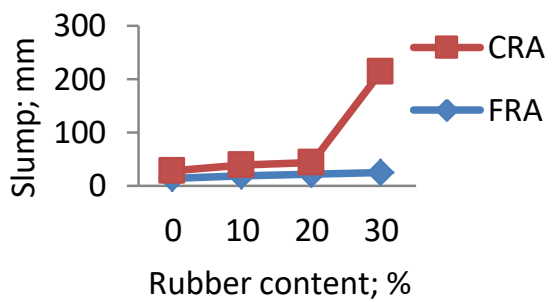

Figure 8: Workability of 1:2:4 at w/c of 0.6

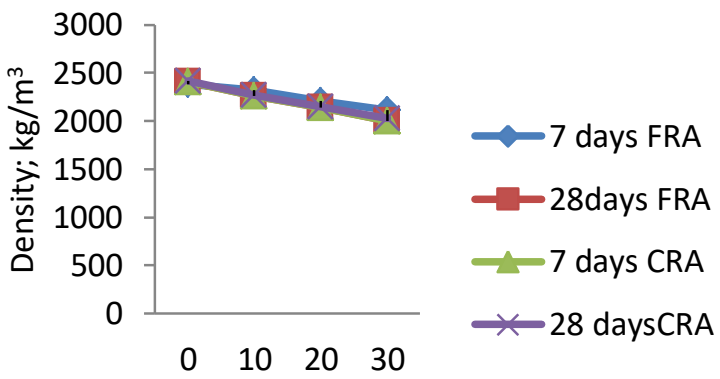

Rubber content; \%

Figure 10: Densities of Mix Proportion 1:11/2:3 at w/c

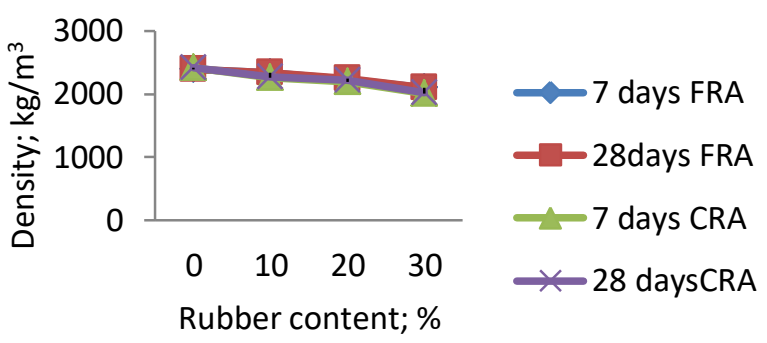

Figure 12: Densities of Mix Proportion 1:2:4 at w/c

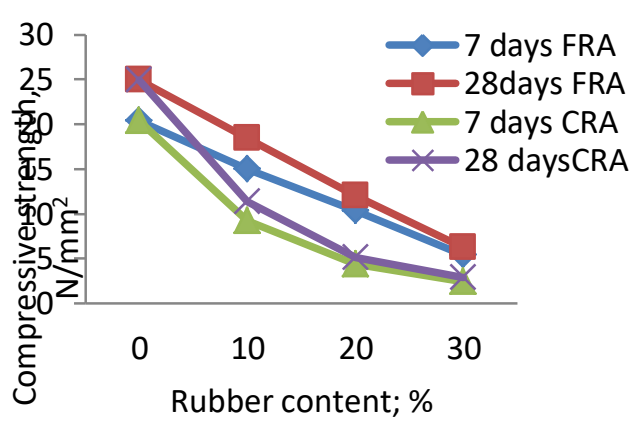




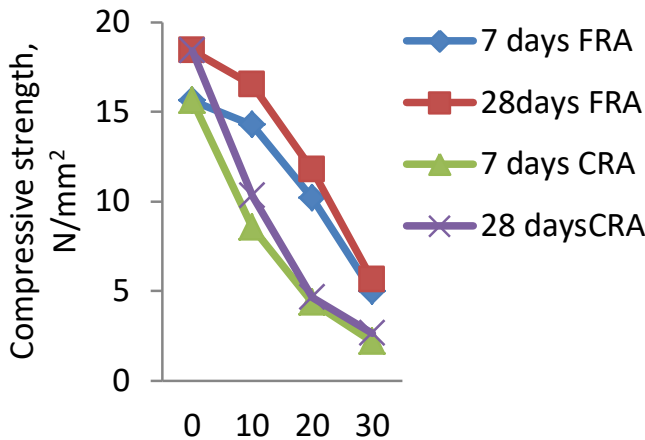

Rubber content; \%

Figure 15: Compressive Strength Tests of 1:2:4 of 0.5 $\mathrm{w} / \mathrm{c}=0.6$

\section{Discussion}

From the experimental results, the slump of the fresh rubberized concrete was observed to decrease with increase in percentage of rubber. This is because of rubber aggregate was unable to absorb water like mineral aggregate resulting in more water that contributes to more workability.

The density of rubberized concrete decreased with increase in the percentage of rubber. This is as a result of the mineral particles being denser than the rubber particles thereby leading to a lighter weight rubberized concrete.

During the process of mixing concrete, the amount of water plays a vital role in the strength achieved. This could lead to drop in compressive strength of rubberized concrete, in addition to the inability of rubber to withstand load. Therefore it could be observed that the lowest compressive strength was at $30 \%$ chipped rubber $\left(3 \mathrm{~N} / \mathrm{mm}^{2}\right)$ which had the most amount of water during mixture.

\subsection{Conclusion}

Upon assessment of the properties of rubberized Bama gravel concrete using crumb and chipped as replacement of both fine and coarse aggregate at $10 \%, 20 \%$ and $30 \%$ respectively, it could be concluded that:

i. There was a decrease in the concrete density and the compressive strength when different percentage of crumb and chipped rubber was added, as a replacement to sand and gravel, were used in the concrete mix.

ii. Concrete cast using chipped rubber as a partial replacement to coarse aggregate shows a significant reduction in the density and compressive strength compared to the control specimens due to low density of rubber.

iii. Concrete cast using crumb rubber as a partial replacement to sand shows a significant increase

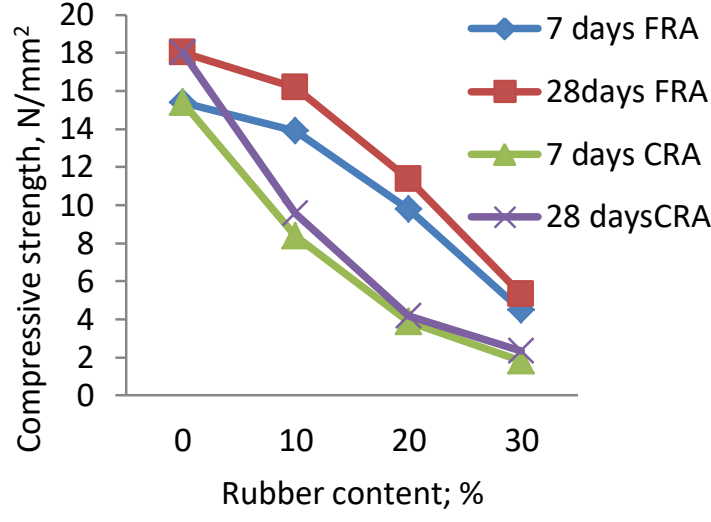

Figure 16: Compressive Strength Tests of 1:2:4 of

in the concrete strength compared to the concrete casted using chipped rubber as a replacement to coarse aggregate

iv. Concrete cast using crumb rubber as a partial replacement to sand shows a reduction in the concrete strength compared to the control specimen. However, significant ductility was observed before failure of the specimens. This is due to the sand having higher density than rubber.

v. Assessment of the physical and mechanical properties of rubberized Bama gravel concrete shows that only $10 \%$ addition of crumb rubber aggregate could be used as a structural member (beams, columns, and slab) due to less than $10 \%$ reduction in compressive strength.

vi. Other percentages of rubber except $10 \%$ crumb rubber aggregate can be used as non structural members due to significant loss in concrete strength.

\section{References}

1. Almaleeh, A. M., Shitote, S. M., \& Nyomboi, T. (2017). Use of waste rubber tyres as aggregate in concrete. Journal of Civil Engineering and Construction Technology, 8(2), 11-19.

2. British Standards Institution (BSI) (2002), BS EN 123903:2002: Testing hardened concrete - Part 3: Compressive strength of test specimens, BSI, London.

3. British Standards Institution (BSI) (2000), BS 410-1: 2000 Test sieves. Technical requirements and testing. Test sieves of metal wire cloth

4. British Standards Institution (BSI) (2000), BS 410-2: 2000 Test sieves. Technical requirements and testing. Test sieves of perforated metal plate.

5. British Standards Institution (BSI) (2000a), BS EN 123502:2000: Testing fresh concrete. Part 2: Slump test, BSI, London.

6. British Standards Institution (BSI) (1992), BS 882:1992: Specification for aggregates from natural sources for concrete, BSI, London.

7. British Standards Institution (BSI) (1990), BS 812-110:1990: Testing aggregates- Methods for determination of aggregate crushing value, BSI, London.

8. British Standards Institution (BSI) (1990), BS 812-112:1990: Testing aggregates- Methods for determination of aggregate impact value, BSI, London. 
Assessment of the Properties of Rubberized Bama Gravel Concrete using Destructive Method

9. British Standards Institution (BSI) (1986), BS 3148:1986 Method of test for water for making concrete, BSI, London.

10. Kamil, E., Kaloush, George, P. E., B., W., \& P.E., H. Z. (2005). Properties of crumb Rubber Concrete. Journal of the Transportation Research Board under the category Materials and Construction, 2, 8-14.

11. Mavoulidou, M., \& Figueiredo, J. (2010). Discarded Tyre Rubber As Concrete Aggregate:A Possible Outlet For Used Tyres. Global NEST Journal, 12(4), 359-367.
12. Onundi, L. O., Izam, Y. D., \& Umar, S. G. (1999). The categorization and assessment of a Local aggregate, Bama gravel for the production of a medium grade concrete. Nigeria journal of Practical Engineering, 1, 32-33. 